\title{
Russell of Russell's viper fame
}

\section{Dr Patrick Russell was a physician as a well as a brilliant naturalist}

The beauty of the snake and its lethal bite prompted me to search for information about the person whose name it carries. His name is Dr Patrick Russell. He came from a large Scottish family. His father, John Russell, was a well known lawyer in Edinburgh. Patrick was his fifth son by his third wife. Three children from John's second marriage and four from his third marriage survived to adulthood. All the children became eminent in their chosen fields. Three were admitted as Fellows of the Royal Society of London.

Patrick, born in 1727, studied Roman and Greek classics in the Edinburgh High School and entered the School of Medicine at the University of Edinburgh. He graduated as a doctor in 1750. The professional career of Dr Patrick Russell can be considered in two phases. The first phase is from 1750 to 1771 when he lived in Syria, and the second phase is from 1781 to 1791 when he lived in India.

\section{Work in Aleppo, Syria}

One of his half-brothers (Alexander Russell) was a physician to a company factory in the town of Aleppo (present day Halab) in Syria. Since graduation Patrick came over to Aleppo and began to work under his half brother.
At that time Aleppo was an important trading post within the Turkish Empire with connections to Syria, Lebanon, Jerusalam, Persia, Iraq and the Far East. Through his brother's influence he studied the various languages, the people of the region and the natural history of the region, especially the reptiles and insects. In 1753 his brother returned to England and wrote a book entitled Natural History of Aleppo and Parts Adjacent. Following his brother's departure Patrick was appointed as the physician to the English factory and he held this post for 18 years. During this period he studied the diseases prevalent in the area. Regular outbreaks of bubonic plague used to occur in Aleppo. Russell studied this disease in detail and made important epidemiological observations on it. He kept detailed records of the mortality trends. During the epidemic in May 1761, in the first week he recorded 171 deaths, and this rose to 670 by the first week of June! He used to treat three to four hundred people in the course of an afternoon and was held in high esteem by all those who came under his care. The Pasha of Aleppo granted Russell the rare privilege to wear a turban. Such an honour was rarely granted to Europeans. In 1771 Patrick returned to Edinburgh. By the time he left Aleppo he was a naturalist with skill and experience. 
On his return he edited and produced an enlarged version of the book initially written by his half brother. During this period he was introduced to two naturalists, Joseph Banks and Daniel Solander, who had recently returned from a voyage on the Endeavour with Captain Cook. Patrick was able to study the large collection of specimens he had brought from Syria with these two naturalists. He was elected a Fellow of the Royal Society in 1777.

\section{Work in the Coromandel Coast, India}

In 1781 Patrick's younger brother Claud was appointed as an administrator to the East India Company in Vizagapatnam, in the presidency of Madras, and Patrick accompanied him. In 1785 Patrick Russell was appointed as the naturalist to the Company based in Carnatic. Over the next three years Patrick studied the plants, fish and serpents in the Carnatic plain which stretches along the coast of Coromandel, south of Madras. He was concerned with the lack of any systematic knowledge about the snakes as well as the effects of snakebite. He gathered information about the habit and reputation of each snake, and their local names. He did experiments to determine whether a snake was venomous by introducing a live animal into the container of the snake and observing signs and symptoms of poisoning. He used the Linnean criteria of the presence or absence of abdominal and of sub-caudal scuta (plate-like scales) to separate his first collection of 43 snakes. He identified three genera in this collection, viz. boa, coluber and anguis. He also came across a poisonous snake called in Telugu language as Katuka rekula poda. The drawing and description of a snake, 4 feet 2 inches long, "the colour of the head and trunk a yellowish-brown; back variegated with above 22 large oblong-oval spots brown in the middle with black borders edged with white" is that of the snake now known as Russell's viper. Patrick Russell established that this was a venomous snake, toxicity being second only to the cobra. Subsequently, he used the dentition in the upper jaw to classify the snakes, and carried out a series of experiments where he studied the clinical features of bites of venomous snakes in dogs and chicken. He described the neurotoxic and haemorrhagic manifestations of viper venoms. In 1791 he left India and returned to England. At that time he was working towards identifying a treatment for snakebite. When returning from India he brought along with him his collection of snake skins and donated it to the Natural History Museum of London. In 1796 he published the first volume of his book entitled An Account of Indian Serpents collected on the Coast of Coromandel. In 1801 and 1802 the first and second parts of the second volume were produced. The third and fourth parts of volume 2 were published after his death in 1807 and 1809.

\section{Naming the viper}

In the publication Naturalist's Miscellany George Shaw, Assistant Keeper of the British (Natural History) Museum, and Fredrick P. Nodder, described and named as the Russelian snake (Coluber russelii) a fine specimen given by Patrick Russell to the British Museum. Over the next century this snake was given several names. In 1890, G A Boulanger, Keeper of the British (Natural History) Museum, entered the name of Vipera russelli in Fauna of British India, and in this form it appeared in the Catalogue of Snakes in the British Museum. Several sub-species of Russell's viper have now been described, and it is fitting that the viper bears the name Russell.

Dr Patrick Russell died after a brief illness in $1805 . \mathrm{He}$ was 78 years old at the time. He never married.

\section{Reference}

Hawgood BJ. The life and the viper of Dr Patrick Russell MD, FRS (1727-1805); physician and naturalist. Toxicon 1994; 32: 1295 1304.

R L Jayakody, Senior Lecturer, Department of Pharmacology, Faculty of Medicine, University of Colombo. 